Article

\title{
Effect on Particulate and Gas Emissions by Combusting Biodiesel Blend Fuels Made from Different Plant Oil Feedstocks in a Liquid Fuel Burner
}

\author{
Norwazan Abdul Rahim 1,2,*, Mohammad Nazri Mohd Jaafar ${ }^{2}$, Syazwana Sapee ${ }^{2}$ and \\ Hazir Farouk Elraheem ${ }^{3}$ \\ 1 Department of Mechanical Engineering, Faculty of Engineering, Universiti Pertahanan Nasional Malaysia, \\ Kem Sg. Besi, 57000 Kuala Lumpur, Malaysia \\ 2 Institute for Vehicle System and Engineering, Faculty of Mechanical Engineering, \\ Universiti Teknologi Malaysia, UTM Skudai, 81310 Johor Bahru, Malaysia; \\ nazri@mail.fkm.utm.my (M.N.M.J.); syazwana.sapee@gmail.com (S.S.) \\ 3 School of Mechanical Engineering, Sudan University of Science and Technology, P.O. Box 407, Khartoum, \\ Sudan; hfae76@gmail.com \\ * Correspondence: norwazan@upnm.edu.my; Tel.: +603-9051-3400
}

Academic Editor: Talal Yusaf

Received: 22 May 2016; Accepted: 26 July 2016; Published: 19 August 2016

\begin{abstract}
This paper focuses on the combustion performance of various blends of biodiesel fuels and diesel fuel from lean to rich mixtures. The biodiesel blend fuel combustion experiments were carried out using a liquid fuel burner and biodiesel fuel made from various plant oil feedstocks, including jatropha, palm and coconut oils. The results show that jatropha oil methyl ester blend 25 (JOME B25) and coconut oil methyl ester blend 25 (COME B25) blended at $25 \%$ by volume in diesel fuel produced lower carbon monoxide (CO) and unburned hydrocarbon (UHC) emissions due to more complete combustion. Overall, JOME B25 had the highest CO emission reduction, at about $42.25 \%$, followed by COME B25 at $26.44 \%$ emission reduction relative to pure diesel fuel. By contrast, the palm oil methyl ester blend 25 (POME B25) showed a 48.44\% increase in these emissions. The results showed that the nitrogen oxides $\left(\mathrm{NO}_{\mathrm{x}}\right)$ emissions were slightly higher for all biodiesel blend fuels compared with pure diesel fuel combustion. In case of sulphur dioxide $\left(\mathrm{SO}_{2}\right)$ and $\mathrm{UHC}$ emissions, all biodiesel blends fuels have significantly reduced emissions. In the case of $\mathrm{SO}_{2}$ emission, the POME B25, JOME B25 and COME B25 emissions were reduced $14.62 \%, 14.45 \%$ and $21.39 \%$, respectively, relative to $\mathrm{SO}_{2}$ emission from combusting pure diesel fuel. UHC emissions of POME B25, JOME B25 and COME B25 showed $51 \%, 71 \%$ and $70 \%$ reductions, respectively, compared to diesel fuel. The conclusion from the results is that all the biodiesel blend fuels are suitable and can be recommended for use in liquid fuel burners in order to get better and 'greener' environmental outcomes.
\end{abstract}

Keywords: biodiesel; blend; combustion; emissions; liquid fuel burner

\section{Introduction}

Nowadays, the primary concern all over the world is to become more environmentally 'green', with very low production of pollution. The new technology developments in s, propulsion or transportation have to focus on advances for achieving reduced formation of pollutants such as nitrogen oxides $\left(\mathrm{NO}_{\mathrm{x}}\right)$, carbon monoxide $(\mathrm{CO})$, carbon dioxide $\left(\mathrm{CO}_{2}\right)$, sulfur dioxide $\left(\mathrm{SO}_{2}\right)$, unburned hydrocarbon (UHC) and soot. An industrial burner is a common technology used in many industries. Currently, the performance of this equipment is enhanced in many ways, including by use of a swirler to improve the combustion droplet uniformity, using biofuels as a way to get lower emissions, and 
designing staged concepts to increase the fuel conversion efficiency. The use of biofuels is the most popular areas of research for improving burner efficiency, and has been investigated here as a way to achieve reduced emissions. Significantly, biofuels are produced from all kinds of resources using many techniques. Biodiesel is one form of biofuel has been widely used as an alternative fuel because it's biodegradable, renewable, non-toxic and has a lower aromatic content [1-3].

'Biodiesel' is a general term covering a number of ester-based oxygenated fuels produced from the fatty acid triglycerides contained in either vegetable oils, animal fats or waste vegetable oils (i.e., used cooking oil). There are two types of vegetable oils feedstocks: edible and non-edible oils. One reason vegetable oils are more attractive than petroleum is because they contain no sulfur [4]. Vegetable oils produced from different plants give different levels and mixes of fatty acids content. Currently, the most common biodiesels are produced from edible plant oils such as palm, soybean, rapeseed, sunflower, coconut oil, etc. However, non-edible oils are also being used for conversion into biodiesel fuels because the production from these does not reduce the amount of vegetable oils available for human use and consumption. These include oils from jatropha, karanja, polanga, mahua, castor and rubber plants [5]. Biodiesel can be produced by various methods such transesterification, dilution, pyrolysis and micro-emulsion [6]. Transesterification is the most popular method because it is considered the most economical one. In addition, this method produces good yields of quality biodiesel.

Palm oil is currently the feedstock providing the largest volume of biodiesel from edible oils. Malaysia is the second largest producer of palm oil for biodiesel production after Indonesia [7]. Palm oil contains four major forms of saturated and unsaturated fatty acids, including palmitic, oleic, linoleic and stearic acids. Palm oil methyl ester (POME) has the greatest potential presently to be a renewable and biodegradable substitute for diesel. POME has relatively low density, is more viscous and contains lower energy/vol and sulphur compared to diesel fuel. Many researchers have been investigating the production of biodiesel from palm oil feedstock, using different methods such as transesterification, which involves using methanol with a catalyst [8,9].

The coconut palm, known as Cocos nucifera Linn, is a member of the family of Arecaceae, and the fruit (the coconut) is a source of another oil used for biodiesel production. Coconut oil is produced in the coastal areas native to the tropical eastern regions. Coconut palms require sandy and saline soil with a shallow water table or rainfall throughout the year [10]. Coconut oil is also one of the edible oils. The free fatty acids (FFAs) of coconut oil include a small percentage with low molecular weight both saturated and unsaturated oils. The most commons FFAs are identified as lauric, myristic, palmitic, stearic, caprylic, capric, oleic and linoleic [11,12]. Indonesia is the largest producer of coconut oil in the Asian region. Jatropha (Jatropha curcas L.) belongs to the Euphorbiaceae family and the oils from this genus are categorized as non-edible oils [13]. Jatropha oil has the potential to become a low-cost biodiesel feedstock. The jatropha seed has a high oil content and when properly managed and with improved genetics can have a high seed yield per unit area [14,15]. This oil consists of a series of saturated and unsaturated acids, which includes oleic and linoleic as main fatty acids. It has good oxidation stability and low viscosity [16]. There are many researchers who have examined the production of biodiesel from jatropha oil as being an inedible oil, its use does not compete with uses by humans for food. The biodiesel made from jatropha oil is being studied in diesel engines, gas turbines and furnace applications and studies include the characterization of the combustion properties of either pure JOME biodiesel or its blends with diesel fuel [17-20]. The authors found that the most jatropha oil-derived biodiesel combustion studies showed production of low emissions of $\mathrm{CO}$ and UHC emissions while the $\mathrm{NO}_{x}$ emissions were increased.

The vegetable oils that have been converted into biodiesel fuel must go through the combustion process in order to get their emission gas characteristics. These biodiesel fuels from different oil sources can be tested in many different forms of combustion systems such as internal combustion engines (either spark-ignition or compression-ignition engines), gas turbines, burners or furnaces. Many studies on biodiesel fuels have been conducted in diesel engines, but there are limited studies in non-transportation applications such as gas turbines and burners [1,21]. Heavy oil combustion shows 
good characteristics such as $\mathrm{NO}_{\mathrm{x}}$ emissions reduction, due to the use of swirl burners in heavy-oil industrial applications [22]. Sáez et al. [23] operated an oil burner with a dual pumping and injection system to test liquid butane and diesel fuel under different pressures ranging from 0.8 to $2.0 \mathrm{MPa}$. The burner was designed to spray the liquid fuel that would then combust in the combustion chamber. It found that the $\mathrm{NO}_{\mathrm{x}}$ emission of combusted liquid butane is lower than that of diesel fuel. In another parameter looked at in the study, the swirling flow is recognized in gas turbines engine or burner combustion as improving the emission characteristics. Feyz et al. [24] investigated the effect of flames with swirling flow. They found the flame stability is sensitive to the change of swirl number.

Ghorbani et al. [25] studied the combustion of biodiesel blends in different volume percentages of B5, B10, B20, B50, B80 and B100 with diesel fuel, examining how the boiler is influenced by airflow. Biodiesel and its blends, except for $\mathrm{B} 10$, emitted less $\mathrm{CO}, \mathrm{SO}_{2}$ and $\mathrm{CO}_{2}$ pollutants compared to diesel. The study found that $\mathrm{B} 10$ emitted less $\mathrm{CO}_{2}$ and $\mathrm{SO}_{2}$. The combustion of biodiesel and their blends showed higher $\mathrm{NO}_{x}$ at the first level of energy input. Thus, the $\mathrm{NO}_{\mathrm{x}}$ results indicated a reduced emission at the second energy level input. Jatropha oil methyl ester (JOME) was blended with diesel fuel to become B15 and B25 and tested for combustion emission parameters using a gas turbine engine. The emission results showed that B15 and B25 have lower CO and UHC emissions while the $\mathrm{NO}_{\mathrm{x}}$ emissions were higher than from combustion of pure diesel fuel [21]. In recent years, many studies have shown that biodiesel and its blends offer good levels of emissions of pollutants such as $\mathrm{CO}$, $\mathrm{SO}, \mathrm{UHC}$, soot, and aromatics, and contain no $\mathrm{SO}_{2}$, even though emissions were not improved for $\mathrm{NO}_{x}$ yet $[26,27]$. Hashimoto et al. [28] studied the combustion characteristics of palm oil methyl ester (POME) in gas turbines at atmospheric pressure using high-temperature air (673K). It was found that POME gave similar results as diesel fuel, but there were indications that increasing the excess air ratio reduced $\mathrm{NO}_{\mathrm{x}}$ emissions. Methyl esters of used palm oil were produced and blended with different volume proportions to give B25, B50 and B75 blends. The results obtained presented lower $\mathrm{CO}$ emissions than diesel fuel, but the combustion of these methyl esters blends produced higher $\mathrm{NO}_{\mathrm{x}}$ emissions [29]. Özcanli et al. [30] was studied castor oil biodiesel blends with volumetric ratios of B5, B10, B25, B50 and B100. The results showed that B25 gives better combustion performances in diesel engines. A few researchers agree that combustion efficiency can be enhanced by using biodiesel fuel because the molecular structure of biodiesel results in a higher oxygen content of the fuel, compared with diesel [31,32].

The properties of biodiesel are the most important characteristics for defining the combustion products. Biodiesel fuel properties are characterized by physicochemical properties including density $\left(\mathrm{kg} / \mathrm{m}^{3}\right)$, viscosity $\left(\mathrm{mm}^{2} / \mathrm{s}\right)$ cetane number, calorific value $(\mathrm{MJ} / \mathrm{kg})$, acid value $(\mathrm{mg} \mathrm{KOH} / \mathrm{g}$-oil), pour point $\left({ }^{\circ} \mathrm{C}\right)$, cloud point $\left({ }^{\circ} \mathrm{C}\right)$, flash point $\left({ }^{\circ} \mathrm{C}\right)$, saponification value and iodine value. The physical and chemical properties of each biodiesel depend on the type of feedstock and its fatty acids composition, based on ASTM 6751-3 and EN14214. Table 1 shows the variation in properties of biodiesels produced from different feedstock vegetable oils. These physicochemical properties of biodiesel will impact on the combustion products produced or emitted.

Table 1. Properties of biodiesel from various feedstocks.

\begin{tabular}{|c|c|c|c|c|c|c|c|c|}
\hline Feedstock & $\begin{array}{c}\text { Kinematic } \\
\text { Viscosity } \\
\left.\text { (cSt, at } 40^{\circ} \mathrm{C}\right)\end{array}$ & $\begin{array}{l}\text { Density } \\
\left(\mathrm{g} / \mathrm{cm}^{3}\right)\end{array}$ & $\begin{array}{l}\text { Saponification } \\
\text { Number }\end{array}$ & $\begin{array}{l}\text { Iodine } \\
\text { Value }\end{array}$ & $\begin{array}{l}\text { Acid Value } \\
\text { (mg KOH/g) }\end{array}$ & $\begin{array}{l}\text { Cetane } \\
\text { Number }\end{array}$ & $\begin{array}{l}\text { Heating Value } \\
(\mathrm{MJ} / \mathrm{kg})\end{array}$ & References \\
\hline Coconut & $2.726-4.1$ & $807.3-877.1$ & - & - & 0.106 & $55.0-60$ & $36.98-38.10$ & {$[6,11,34]$} \\
\hline Soybean & $4.039-4.1$ & $885-913.8$ & - & 0.266 & $128-143$ & $37.9-51$ & $37.3-39.76$ & {$[6,33]$} \\
\hline Rapeseed & $4.44-4.7$ & $882-887$ & - & - & - & 53 & 37 & {$[6,33]$} \\
\hline Karanja & 6.13 & 931 & - & - & $0.3-5.06$ & 55 & $34-43.42$ & {$[6,36]$} \\
\hline Polanga & 4 & 888.6 & - & - & - & 57.3 & 39.25 & [34] \\
\hline $\begin{array}{l}\text { Moringa } \\
\text { Oliefera }\end{array}$ & 5.05 & 869.6 & 199 & 77.5 & 8.62 & 56.3 & 40.05 & {$[38]$} \\
\hline
\end{tabular}


The interest in this study was to evaluate the emissions characteristics of jatropha oil methyl ester (JOME 25), palm oil methyl ester (POME B25) and coconut oil methyl ester (COME B25) compared with diesel fuel emissions. The advantages of potential use of biodiesel blend fuels in liquid fuel burners can thus be determined and assessed from this study.

\section{Material and Methods}

\subsection{Materials and Chemicals}

Each vegetable oil was put through the common procedure of homogeneous catalyzed transesterification process, specifically the process of alkaline-catalyzed transesterification, being the cheapest method [39]. Transesterification is the one of the main methods that has been used in many studies due to its low cost and because it is easy to perform [40,41]. Commonly this method uses potassium hydroxide $(\mathrm{KOH})$ or sodium hydroxide $(\mathrm{NaOH})$ as a catalyst because these are easily soluble in the alcohols used. As shown in Figure 1, the transesterification method involves a reaction between the triglyceride and the alcohol in the presence of the catalyst to produce alkyl esters and glycerin as products. However, this method is only efficient if the amount of FFA in the oil does not exceed $1 \%$ by weight. Conversely, if the percentage of FFAs exceeds $1 \%$ by weight, an additional step of the biodiesel production process must be performed which is known as the esterification process. As reviewed in many studies, vegetable oils may contain high FFA percentages and should be esterified before going through transesterification [42]. The esterification process is done as the necessary step to reduce the amount of FFA in the oil to $1 \%$ or below by weight. Normally, esterification involves a chemical reaction between the oil and an alcohol plus a catalyst (either an acid or alkaline catalyst) to form the alkyl ester as the product [43]. Acid-catalyst esterification is one of most the efficient and economic processes proven to reduce the percentage of FFA in the oil. When necessary, this additional step can be performed in order to produce the corresponding fatty acid alkyl ester. Many studies have attempted to use a two stage process of acid-catalyst esterification and alkaline-catalyst transesterification to complete the process of biodiesel production. The presence of catalyst is necessary in both methods to increase the reaction rate and the yield of biodiesel [39].

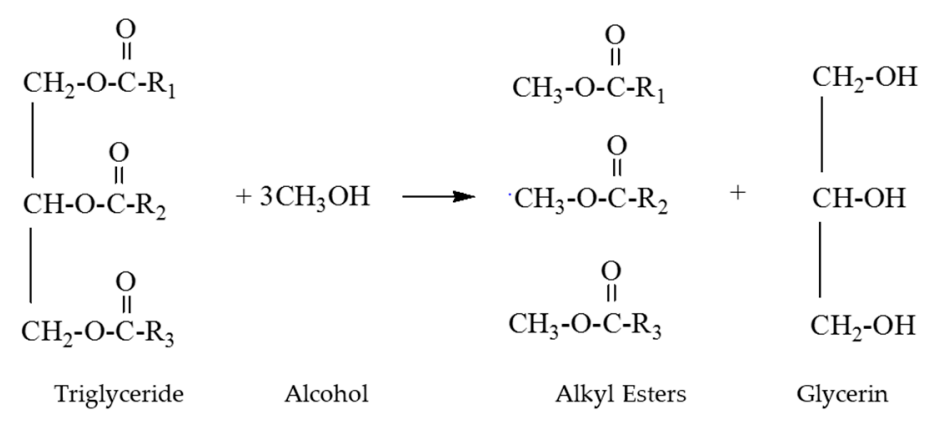

Figure 1. Transesterification reaction of a triglyceride and an alcohol.

The three different forms of vegetable oil used to produce biodiesel in this work were oil from Jatropha curcas, refined palm oil and refined coconut oils. Jatropha oil is categorized as a non-edible oil, and the material used for this research was obtained from Bionass Sdn Bhd (Kuala Lumpur, Malaysia). This oil required use of the esterification process due to the high long-chain fatty acid value of the triglyceride, while the refined palm and coconut oil (classified as edible-oils) were only put through the homogeneous transesterification process, which is where the triglyceride reacts with an alcohol in presence of a catalyst, producing a mixture of fatty acids alkyl esters and glycerol. Both the esterification and transesterification process used analytical grade methanol, sulfuric acid $\left(\mathrm{H}_{2} \mathrm{SO}_{4}\right)$ and potassium hydroxide $(\mathrm{KOH}) . \mathrm{KOH}$ was used in this transesterification method due to its low cost. The transesterification reaction process to produce biodiesel must be performed with certain 
molecular ratios of alcohols and catalyst [32]. The commonly used transesterification method produces fatty acid methyl esters by using alcohols (either methanol or ethanol) and provides a biodiesel product with a significant reduction in viscosity compared with the feedstock oil [44]. This reaction process is completed with a lower amount of the catalyst used (whether it is acid catalyst or alkaline catalyst) [45].

\subsection{Biodiesel Production Procedures}

The first stage of the production of biodiesel from jatropha oil involved the esterification process using methanol and $\mathrm{H}_{2} \mathrm{SO}_{4}$ at 12:1 molar ratio. Jatropha curcas oil $(300 \mathrm{~mL})$ was heated in a three-neck flask $(500 \mathrm{~mL})$ to $60^{\circ} \mathrm{C}$. Then a $12: 1 \mathrm{molar}$ ratio $(50 \% \mathrm{v} / \mathrm{v}$ of oil) of methanol was measured and added into the pre-heated oil, followed by $1 \%\left(\mathrm{w} / \mathrm{w}\right.$ oil) of $\mathrm{H}_{2} \mathrm{SO}_{4}$. This process was conducted for $3 \mathrm{~h}$ at $60{ }^{\circ} \mathrm{C}$ with use of a thermometer, mechanical stirrer at $400 \mathrm{rpm}$ stirring speed and a reflux condenser to condense the methanol escaping from the reaction mixture. After the esterification process was completed, the reaction oil was poured into a separatory funnel for $2 \mathrm{~h}$ to separate the oil from the excess alcohol and $\mathrm{H}_{2} \mathrm{SO}_{4}$. The lower layers of oil were put into a three-neck flask and subsequent testing showed that the acid value was less than $3 \mathrm{mg} \mathrm{KOH} / \mathrm{g}$ oil.

After the esterification process, the most common method used to produce biodiesel is a homogeneous transesterification process. The triglyceride was reacted with $25 \%$ (v/v oil) of methanol (or 6:1 molar ratio) and $1 \%\left(\mathrm{~m} / \mathrm{m}\right.$ oil) catalyst of $\mathrm{KOH}$ at $60^{\circ} \mathrm{C}$. The triglyceride, alcohols and the catalyst of $\mathrm{KOH}$ were reacted in the same equipment used in the previous process under reflux for $2 \mathrm{~h}$ and $400 \mathrm{rpm}$ stirring speed. Then the products were poured into a separatory funnel over up to $12 \mathrm{~h}$ to separate the biodiesel and the glycerol. The bottom layer containing the glycerol and impurities was drawn off.

The methyl esters formed in the transesterification reaction were put through a post-treatment consisting of washing with warm $\left(50{ }^{\circ} \mathrm{C}\right)$ distilled water five times to remove the excess alcohol, catalyst and residual glycerol. The ratio of distilled water to methyl ester used was 2:1. The process was continued with heating to $110^{\circ} \mathrm{C}$ and stirring of the methyl ester in the beaker to drive out the moisture and any remaining methanol. The fatty acid methyl ester (FAME) was filtered at room temperature using a funnel and filter paper, and then stored in a bottle. Finally, the FAME was blended with the diesel fuel at $25 \%$ by volume and named as B25 for each feedstock which was used to produce each fatty acid methyl ester (FAME). They were organized by the different FAME names: palm oil methyl ester (POME B25), coconut oil methyl ester (COME B25) and jatropha oil methyl ester (JOME B25). The biodiesel fuels were mixed with diesel fuel using a mixer. These mixed fuels were stirred in the mixer until their specific gravity achieved homogeneity. Then the specific gravity (SG) was checked for each fuel blend to ensure the mixing had been identical. Table 2 (below) shows the physical and chemical characters of the three types of FAMEs including their standard values and limits.

Table 2. Physical and chemical characterization of various biodiesel fuels.

\begin{tabular}{|c|c|c|c|c|c|c|c|}
\hline Property & Unit & Test Method & JOME & POME & COME & DIESEL & Standard Limits \\
\hline Density at $15^{\circ} \mathrm{C}$ & $\mathrm{kg} / \mathrm{m}^{3}$ & ASTM D1298 & 0.8717 & 0.865 & 0.862 & 0.835 & $860-900$ \\
\hline Kinematic viscosity at $40^{\circ} \mathrm{C}$ & $\left(\mathrm{mm}^{2} / \mathrm{s}\right)$ & ASTM D445 & 4.521 & 4.488 & 2.903 & 3.619 * & $1.9-6$ \\
\hline Acid value & $(\mathrm{mg} \mathrm{KOH} / \mathrm{g})$ & ASTM D664 & 0.515 & 0.545 & 0.265 & - & 0.5 maximum \\
\hline Flash point & ${ }^{\circ} \mathrm{C}$ & ASTM D93 & 170 & 174 & 106 & $77 *$ & $>130{ }^{\circ} \mathrm{C}$ minimum \\
\hline Pour point & ${ }^{\circ} \mathrm{C}$ & ASTM D97 & -6 & 15 & -3 & $-20 *$ & -15 to -16 \\
\hline Cloud Point & ${ }^{\circ} \mathrm{C}$ & ASTM D2500 & 6 & 11 & 6 & $-35 *$ & -3 to -12 \\
\hline Cetane number & - & ASTM-D613 & 54.8 & 59.2 & 64.6 & $48 *$ & 47 minimum \\
\hline CFPP Cold Filter Plugging Point) & ${ }^{\circ} \mathrm{C}$ & ASTM D6371 & 1 & 13 & 1 & $44.7 *$ & $\operatorname{Max}+5$ \\
\hline Calorific value & $(\mathrm{kJ} / \mathrm{kg})$ & ASTM-D240 & 39.7 & 39.4 & 37.6 & - & Report \\
\hline Oxidation stability, $110^{\circ} \mathrm{C}$ & hours & EN 15751 & 2.1 & 7.5 & 18.8 & - & $3 \mathrm{~h}$ minimum \\
\hline Carbon residue (on $100 \%$ sample) & $\% \mathrm{~m} / \mathrm{m}$ & ASTM D4530 & 0.01 & 0.01 & 0.01 & - & 0.050 maximum \\
\hline Carbon & $\%$ wt & ASTM PS 121 & 76.7 & 76.2 & 72.6 & - & 77 \\
\hline Hydrogen & $\% w t$ & ASTM PS 121 & 12.6 & 12.7 & 12.7 & - & 12 \\
\hline Nitrogen & $\% w t$ & ASTM PS 121 & $<0.1$ & 0.1 & $<0.1$ & - & - \\
\hline Oxygen & \%wt & ASTM PS 121 & 10.8 & 11.0 & 14.7 & - & 11 \\
\hline Total sulphur & $\mathrm{mg} / \mathrm{kg}$ & ASTM 5453-12 & 1.8 & 2.2 & 1.9 & - & 15 maximum \\
\hline
\end{tabular}

* Data collected from Ref. [38]. 


\section{Experimental Work}

The combustion of biodiesel fuels was set up using the combustion rig and gas analyzer. The rig was built up with the fuel line system, airflow system, igniter, nozzle, axial swirler, combustion chamber and gas analyzer system as shown in Figure 2. Initially, the experiment was carried out to evaluate the $S_{N}$ effect with three different $S_{N}$ of $0.463,0.630$ and 0.895 . Then, the study was continued with the various biodiesel blend feedstocks using the appropriate $S_{N}$. The fuel flow rate was fixed for each case as measured and as appropriate with the nozzle used. The fuels were sprayed through the nozzle at a consistent pressure of 15.5 bars. The air mass flow rate was controlled by the starter box and the flow meter used to measure equivalence ratios from lean to rich mixture region. In this study, the equivalence ratio was set up from 0.6 up to 1.3 and emissions data were measured. When the burner was switched on, the air mass flow rate was reached at the point needed as displayed on the flow meter, and combustion occurred horizontally inside the combustion chamber. Then the data of emissions and temperature was recorded.

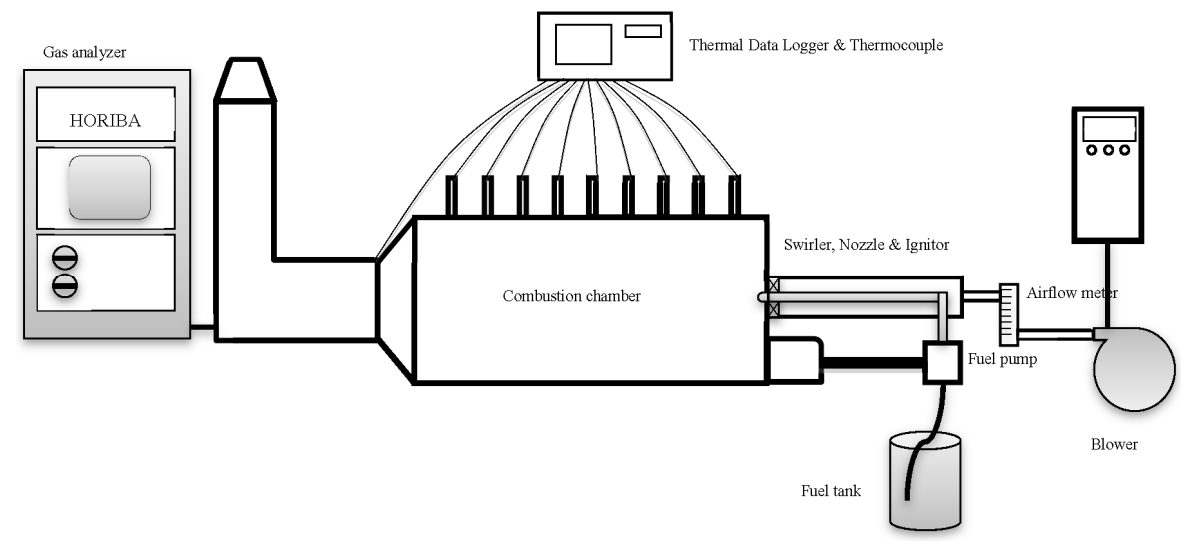

Figure 2. Burner rig layout.

This analyzing system of combustion products used the ENDA-5000 series stack-gas analyzer system by Horiba (Kyoto, Japan). The system accurately measured the $\mathrm{NO}_{\mathrm{x}}, \mathrm{SO}_{2}, \mathrm{CO}, \mathrm{CO}_{2}$ and $\mathrm{O}_{2}$ of the dry flue gases in real time. The exhaust temperature measurement was carried out at the end of chamber using thermocouple attached to the data logger. The specifications of the gas analyzer are listed in Table 3.

Table 3. Technical characteristics of the ENDA-5000 series gas analyzer.

\begin{tabular}{ccc}
\hline Parameter & Measuring Range & Measurement Method \\
\hline $\mathrm{NO}_{\mathbf{x}}$ & $200-5000 \mathrm{ppm}$ & NDIR \\
$\mathrm{SO}_{2}$ & $200-5000 \mathrm{ppm}$ & NDIR \\
$\mathrm{CO}$ & $200-5000 \mathrm{ppm}$ & NDIR \\
$\mathrm{CO}_{2}$ & $5-25 \mathrm{vol} \%$ & NDIR \\
$\mathrm{O}_{2}$ & $10-25 \mathrm{vol} \%$ & Magneto-pneumatic detection \\
\hline
\end{tabular}

In this study, $\mathrm{NO}_{\mathrm{x}}, \mathrm{CO}, \mathrm{SO}_{2}$ and $\mathrm{UHC}$ emissions were evaluated with their volumetric concentration in the exhaust gas corrected to $16 \% \mathrm{O}_{2}$. The corrected concentration was calculated by the following equation:

$$
X_{16 \% \mathrm{O}_{2} i}=X_{\text {measured, } i} \frac{(20.99-16)}{\left(20.99-X_{m, \mathrm{O}_{2}}\right)}
$$

where $\mathrm{X}_{16 \% \mathrm{O}_{2} i} ; \mathrm{X}_{\text {measured, } i}$ and $\mathrm{X}_{m, \mathrm{O}_{2}}$ are the concentration corrected to $16 \% \mathrm{O}_{2}$ of species $i(\mathrm{ppm})$, the measured concentration of species $i$ in the exhaust gas (ppm) and the measured concentration of $\mathrm{O}_{2}$ in the exhausted gas (\%), respectively [45]. 
An axial swirler was attached inside the burner rig. The swirler was used to produce a swirling flow and generate better mixing of air and fuel to promote complete combustion. The swirler generates a swirling flow and the swirl number depends on the swirl angle of the vanes used. The swirl number $\left(S_{N}\right)$ which is used here is defined by Chigier and Beer [46]:

$$
\mathrm{S}_{N}=\frac{\mathrm{G}_{\theta}}{\mathrm{G}_{\mathrm{x}} \mathrm{R}}
$$

where:

$$
\mathrm{G}_{\theta}=\int_{0}^{\mathrm{R}} \rho(\mathrm{Wr}) \mathrm{u} 2 \pi \mathrm{r} \mathrm{dr}
$$

and:

$$
\mathrm{G}_{\mathrm{x}}=\int_{0}^{\mathrm{R}} \rho \mathrm{U}^{2} 2 \pi \mathrm{r} d \mathrm{r}
$$

where $U, W$ and $\rho$ are the axial velocity, tangential velocity and density respectively. For the axial swirler, the swirl number is related to the swirl angle, $\theta$, inner $r_{i}$ and outer radius $r_{0}$ as given by [47] where the swirl number was proportional to $\tan \theta[48]$ :

$$
\mathrm{S}_{\mathrm{N}}=\frac{2}{3}\left(\frac{1-\left(\frac{\mathrm{r}_{\mathrm{i}}}{\mathrm{r}_{0}}\right)^{3}}{1-\left(\frac{\mathrm{r}_{\mathrm{i}}}{\mathrm{r}_{0}}\right)^{2}}\right) \tan \theta
$$

This experiment was carried out to investigate the effect on emission gases of three different types of biodiesel blends fuel: POME B25, JOME B25 and COME B25. The experiment was devised to define the effect of swirler number when using diesel fuel as a medium for combustion. Then, the experiment was continued with all three types of biodiesel blends fuel and diesel fuel which have been combusted and the observations on their emissions of $\mathrm{NO}_{x}, \mathrm{CO}, \mathrm{SO}_{2}$ and UHC gases. Subsequently, the exhaust temperatures of all biodiesel blends combustion were considered in order to observe their relation to $\mathrm{NO}_{\mathrm{x}}$ emissions.

\section{Results and Discussion}

A liquid fuel burner was designed to evaluate biodiesel blend combustion performance and emissions formation. In order to get better emissions reduction, an axial swirler has been attached and utilized with the system. The experiment tests were performed in an atmospheric pressure combustion set-up. With respect to swirl angle, this parameter has the potential to produce different effects on atmospheric pollutant emissions. There were three different angles of swirl used in the liquid fuel burner to observe which swirl angle is suitable for further study on biodiesel fuel. The swirl numbers are calculated as $S_{N}=0.436, S_{N}=0.630$ and $S_{N}=0.895$, corresponding to $30^{\circ}, 40^{\circ}$ and $50^{\circ}$ swirl angles, respectively. The air is supplied from a blower that axially conducts air to the swirler at the entrance of the combustion chamber. The airflow rate was varied to pass air through the swirler that showed its influence on emissions. Thus, it is shown that using a swirler does help in mixing air and fuel prior to ignition and leads to more complete combustion. The fuel supply using the nozzle was fixed in the constant mass flow rate. In this entire experimental work, the emissions from the lean to rich mixture combustion were studied.

Diesel fuel was used to evaluate the effect of $S_{N}$ on the combustion characteristics, and specifically on emissions formation. Figure 3 shows the result of $\mathrm{NO}_{x}$ emissions variation with $\mathrm{S}_{\mathrm{N}}$. The $\mathrm{NO}_{\mathrm{x}}$ emissions increased with larger $S_{N}$. $\mathrm{NO}_{x}$ emissions at $\mathrm{S}_{\mathrm{N}}=0.895$ were the highest readings from the range of lean up to rich mixtures compared to $S_{N}=0.436$ and $S_{N}=0.630$ that have lower values. Consequently, the second larger $\mathrm{S}_{\mathrm{N}}$ of 0.630 has lower $\mathrm{NO}_{\mathrm{x}}$ than $\mathrm{S}_{\mathrm{N}}=0.895$, followed by the lowest $\mathrm{S}_{\mathrm{N}}$ of 0.436 which has the lowest $\mathrm{NO}_{\mathrm{x}}$. On average these two lowest $\mathrm{S}_{\mathrm{N}}$ values have quite similar $\mathrm{NO}_{\mathrm{x}}$ emissions figures. The higher $\mathrm{NO}_{\mathrm{x}}$ emissions figure corresponding to $\mathrm{S}_{\mathrm{N}}=0.895$ was due to the 
larger recirculation zone inside the chamber leading to more complete combustion. Thus, higher $\mathrm{NO}_{\mathrm{x}}$ emissions were produced.

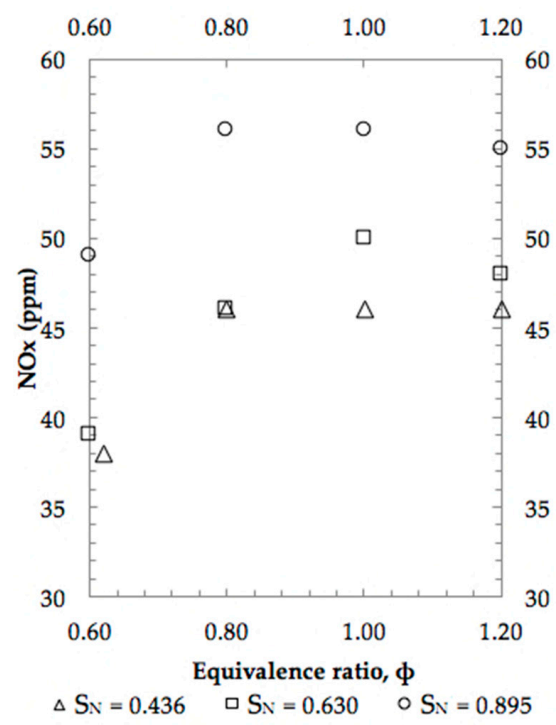

Figure 3. $\mathrm{NO}_{\mathrm{x}}$ emissions of various $\mathrm{S}_{\mathrm{N}}$.

CO emissions decreased from the lean to rich mixtures, while they increased for $\mathrm{S}_{\mathrm{N}}=0.895$ after they reached stoichiometric values. The larger the $S_{N}$, the lower was the $C O$ emission result until the equivalence ratio, $\varphi=1.0$. Then, $\mathrm{CO}$ slightly increased towards rich region of combustion. The $\mathrm{S}_{\mathrm{N}}$ of 0.895 improved the $\mathrm{CO}$ emissions because the largest swirl angle was gives a higher tangential velocity and this is associated with changes in the structure of the center recirculation zone (CRZ). In this case, a larger $\mathrm{S}_{\mathrm{N}}$ promotes better air-fuel mixing that leads to more complete combustion. Thus, the $\mathrm{CO}$ emission is improved overall during the combustion. The $S_{N}$ values of 0.630 and 0.436 corresponding to swirl angles of $40^{\circ}$ and $30^{\circ}$ have higher $\mathrm{CO}$ values, but as observed in Figure 4, the trends of $\mathrm{CO}$ emissions were reduced towards the stoichiometric region. In the stoichiometric region, all swirl angles produced approximately the same $\mathrm{CO}$ emissions values. In the stoichiometric region, the $\mathrm{CO}$ formation of $\mathrm{S}_{\mathrm{N}}=0.895$ was higher by dissociation of a higher flame temperature. $\mathrm{CO}$ is formed owing to the lack of sufficient oxygen to complete the $\mathrm{CO}_{2}$ formation reaction of [49].

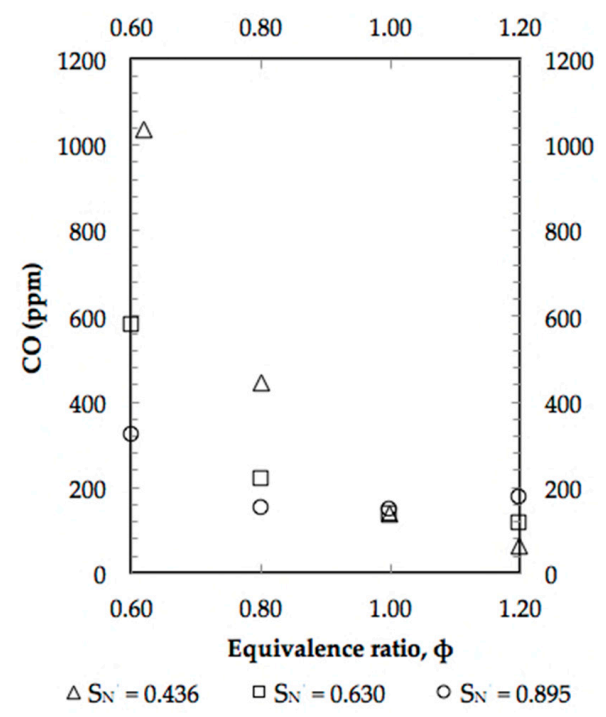

Figure 4. $\mathrm{CO}$ emissions of various $\mathrm{S}_{\mathrm{N}}$. 
Figure 5 shows the measurement of $\mathrm{CO}_{2}$ emissions from the exhaust flue gases for each case. Higher concentrations of $\mathrm{CO}$ are shown to reduce $\mathrm{CO}_{2}$ formation. For $\mathrm{S}_{\mathrm{N}}=0.895$, the emission of $\mathrm{CO}_{2}$ was higher than that of $\mathrm{CO}_{2}$ for $\mathrm{S}_{\mathrm{N}}$ of 0.630 and for 0.436 , which is more favorable to the environment. This $\mathrm{CO}$ conversion into $\mathrm{CO}_{2}$ is accelerated to produce less $\mathrm{CO}$ in the flue gases. Overall, the $\mathrm{CO}_{2}$ emissions were increased from the equivalence ratio of 0.60 towards the equivalence ratio of 1.20.

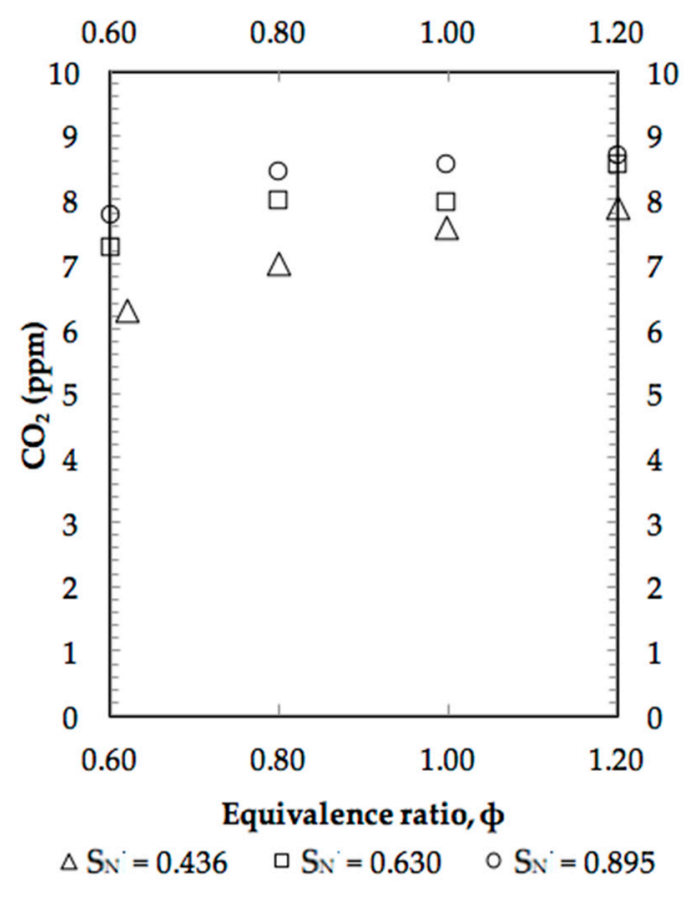

Figure 5. $\mathrm{CO}_{2}$ emissions of various $\mathrm{S}_{\mathrm{N}}$.

Lower $\mathrm{S}_{\mathrm{N}}$ promotes the production of more sulfur at the leaner settings and a reduction is seen toward the stoichiometric state as it approaches the rich combustion mixture. In a contrary trend to this, for the $\mathrm{S}_{\mathrm{N}}$ of 0.630 and 0.895 , the $\mathrm{SO}_{2}$ formations are slightly increased and remained constant when a stoichiometric state was achieved, as shown in Figure 6. Overall, the highest $S_{N}$ had the lowest sulfur emission level.

In respect of UHC levels, a higher figure for $S_{N}$ is essential for reducing UHC emissions because it provides better reagent mixing inside the chamber. Figure 7 shows that the $S_{N}$ of 0.895 has the lowest UHC emission from lean to rich mixtures and produced zero UHC when a stoichiometric state of combustion was reached. This swirl angle has good mixing of air-fuel that leads to complete combustion. $S_{N}$ of 0.630 has higher UHC than $S_{N}$ of 0.895 , while $S_{N}$ of 0.436 has the highest of all swirl angles. From the overall results above, it was found that the highest $S_{N}$ of 0.895 , representing a swirl angle of $50^{\circ}$, results in better emissions, which are suitable for applying to biodiesel application in a liquid fuel burner.

In the initial state, it was observed that there were no significant changes in the spray characteristics for all blends of biodiesel fuels and diesel fuel. The spray and ignition of POME B25, JOME B25 and COME B25 blends performed as well as diesel fuel. Combustion of all liquid fuels occurs when the fuel mixes with air and combusts in the chamber. This combustion produces the emission products at the end of the system, which is otherwise known as the exhaust system. The combustion products that are produced depend on the types of fuels, whether from fossil fuels or biofuels. 


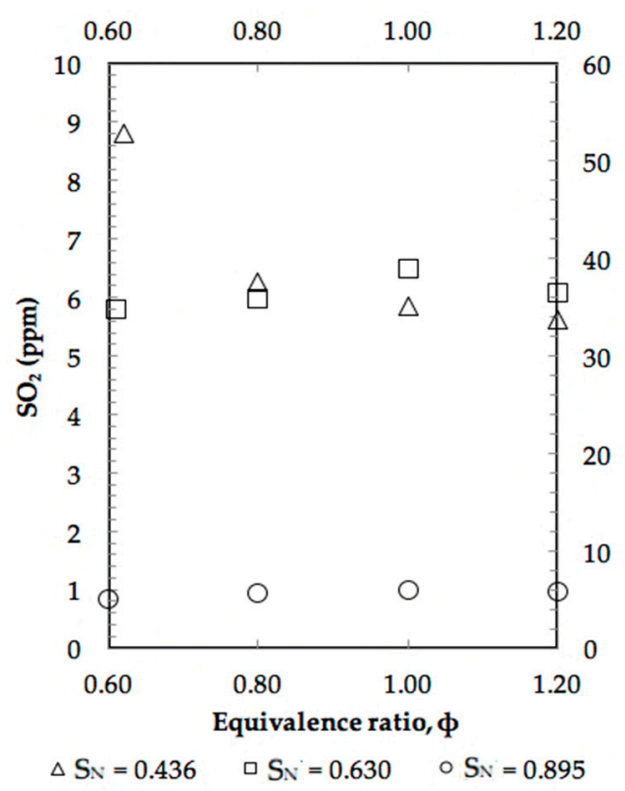

Figure 6. $\mathrm{SO}_{2}$ emissions of various $\mathrm{S}_{\mathrm{N}}$.

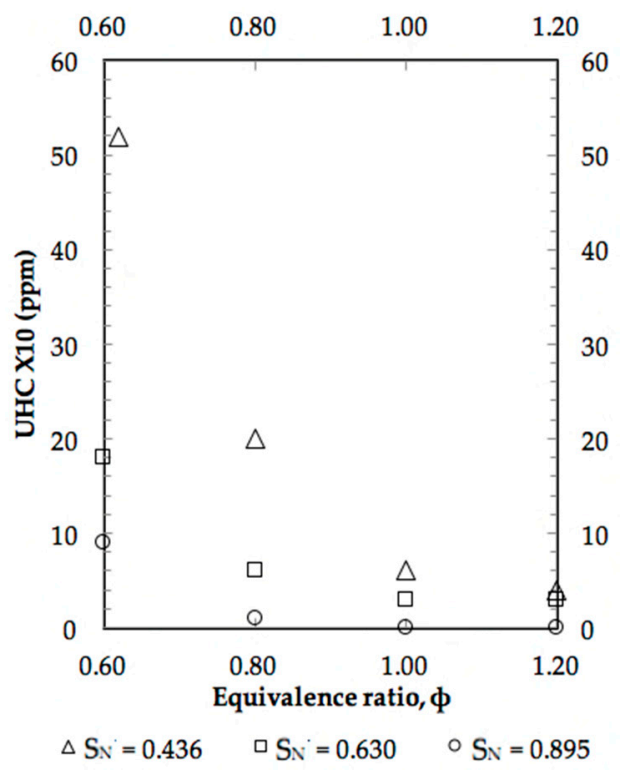

Figure 7. UHC emissions of various $\mathrm{S}_{\mathrm{N}}$.

This study focuses on the need to use biodiesel blend fuels to meet the 'green' environmental criteria. In this study various percentages of biodiesel fuels were blended with diesel fuel to determine the optimum biodiesel percentages. The emissions of $\mathrm{NO}_{x}, \mathrm{CO}, \mathrm{SO}_{2}$, and $\mathrm{UHC}$ of each feedstock biodiesel blend were evaluated and compared with the emissions obtained with combustion of pure diesel fuel. In this section, the term B25 represents as $25 \%$ of volume of biodiesel mixed with $75 \%$ of diesel fuel. The emission of each biodiesel fuel blend was studied in combustion of lean to rich mixtures using the liquid fuel burner. Three different types of biodiesel, produced from jatropha, palm and coconut oil were prepared in blends with pure diesel using similar volume percentages. There are denoted as JOME B25, POME B25 and COME B25, respectively, where the numerical value denotes the biodiesel percentage in the blends.

The $\mathrm{NO}_{\mathrm{x}}$ emissions attributed to the stoichiometric region for JOME B25, POME B25, COME B25 and diesel fuel are 64 ppm, 60 ppm, 59 ppm, and 56 ppm respectively, as shown in Figure 8. 
As shown in this figure, JOME B25, POME B25, and COME B25 give $14 \%, 7 \%$ and $5 \%$ higher $\mathrm{NO}_{\mathrm{x}}$ than diesel fuel, respectively. As shown in Figure 8, the $\mathrm{NO}_{\mathrm{x}}$ emissions of JOME B25 blend fuel are higher compared to the other fuels. At the early lean state of combustion, the $\mathrm{NO}_{\mathrm{x}}$ emissions have their lowest values and keep increasing at certain points. The results are presented in similar trends except for POME B25 blend. Overall, biodiesel blend fuels give higher $\mathrm{NO}_{\mathrm{x}}$ emissions due to the higher temperature in the combustion zone inside the chamber. Moreover, higher combustion temperatures were observed, which were assumed to be caused by complete combustion due to the higher oxygen content in biodiesel fuel compared to diesel fuel [14,35].

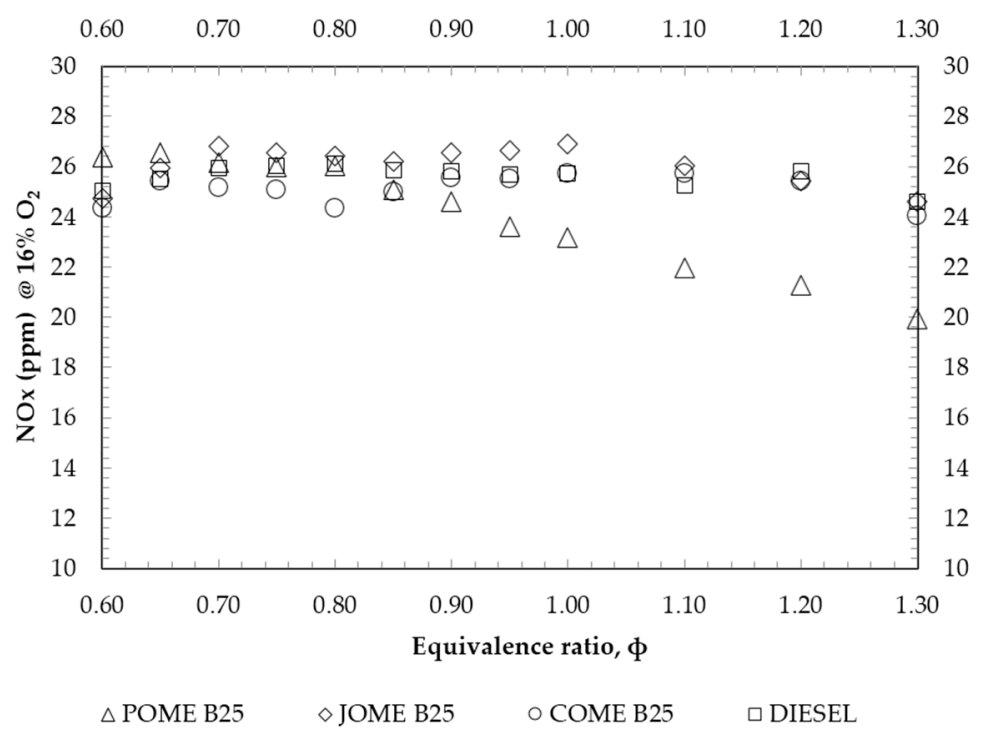

Figure 8. Emissions of NOx for various biodiesel blend fuels.

Figure 9 shows the trend of $\mathrm{CO}$ emissions of each blend and diesel fuel, which are approximately the same from lean up to a stoichiometric state of combustion, except for POME B25 blend fuel. As seen in this graph, the CO emissions for JOME B25 and COME B25 are lower than for diesel fuel over the whole range of combustion regions. Conversely, the CO emission of POME B25 blend fuels has the highest value compared to diesel fuel but slightly lower in the stoichiometric region range of. Overall, the lowest values of $\mathrm{CO}$ emissions were observed in the stoichiometric region. The results show that a better combustion quality was correlated with lower $\mathrm{CO}$ emissions, and this happened with the highest fraction of biodiesel being blended with diesel fuel. JOME B25 shows much lower CO emissions than diesel fuel and other biodiesel blends, as shown in Figure 9. There are certain factors that affect $\mathrm{CO}$ emissions such as air-fuel ratio, engine speed, injection timing, atomization rate and fuel type [37,49]. As reported by Kalam et al. [50], C5 and P5 combustion reduced CO emissions 7.3\% and $21 \%$ compared to diesel fuel, even though C5 has the lowest viscosity. It found that P5 has lower $\mathrm{CO}$ emissions due to the effect of the high unsaturated fatty acids in palm oil. Mofijur et al. [37] found that PB10 and MB10 which have higher viscosity produced lower CO levels. It was also observed that this happened in the stoichiometric region of combustion for all biodiesel blends. As the $\mathrm{O}_{2}$ concentration in the fuel blends is enhanced with higher biodiesel percentage in the blends, more complete combustion occurs, even though POME B25 was shown as not performing as well as other biodiesel blends. 


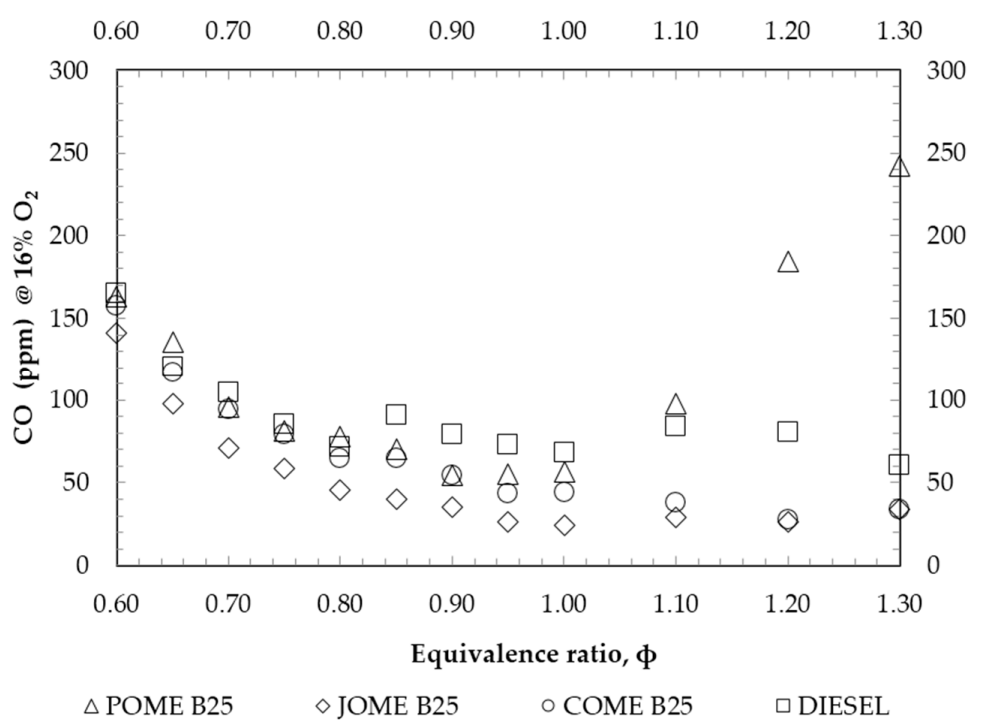

Figure 9. Emissions of $\mathrm{CO}$ for various biodiesel blend fuels.

Figure 10 shows the $\mathrm{SO}_{2}$ emission content in flue gases from the combustion of biodiesel blends and diesel fuels. As observed, $\mathrm{SO}_{2}$ emissions increase from lean to rich mixtures and have a similar trend for each biodiesel blend fuel. However, the diesel fuel emits higher $\mathrm{SO}_{2}$ emissions than biodiesel blend fuels due to lower sulfur content in biodiesel fuels and their lower pollution output properties. Normally, the $\mathrm{SO}_{2}$ emissions emitted from the biodiesel fuel are raised due to the sulfur content that is affected by the esterification process using $\mathrm{H}_{2} \mathrm{SO}_{4}$.

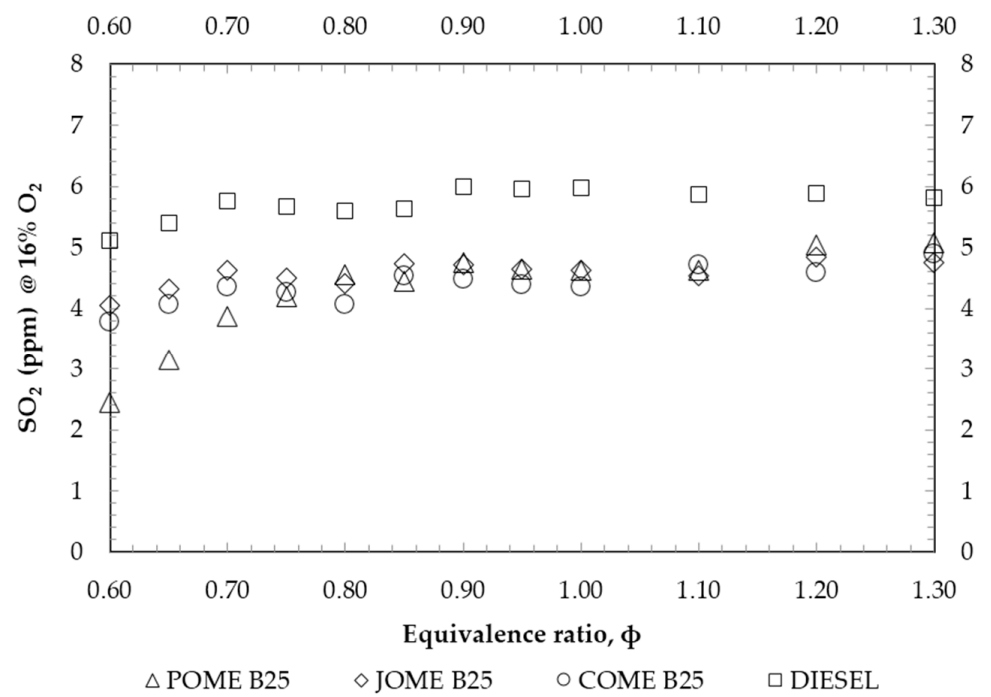

Figure 10. Emissions of $\mathrm{SO}_{2}$ for various biodiesel blend fuels.

Figure 11 presents the $\mathrm{CO}_{2}$ emissions from combustion of biodiesel blends and diesel fuel. $\mathrm{CO}_{2}$ emissions in biodiesel fuels were attributed to the $\mathrm{O}_{2}$ which reacts with unburned carbon atoms during combustion and increases the formation of $\mathrm{CO}_{2}$. The higher level of $\mathrm{CO}_{2}$ emissions indicate the complete combustion and reduction of the $\mathrm{CO}$ level. Overall, biodiesel blend combustion produces higher $\mathrm{CO}_{2}$ levels than does combustion of diesel fuel, but the COME B25 blend combustion shows lower $\mathrm{CO}_{2}$ in the early lean region. This may be due to incomplete combustion. At an equivalence ratio of 0.9 , the $\mathrm{CO}_{2}$ emission of COME B25 blend increased to become higher than the diesel fuel $\mathrm{CO}_{2}$ emissions. 


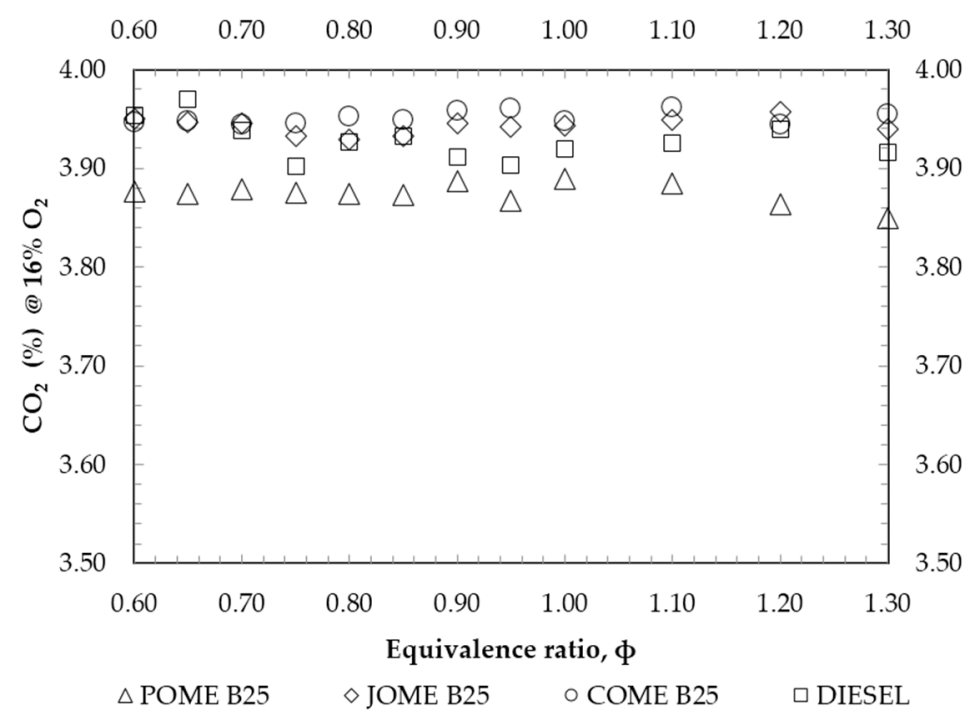

Figure 11. Emissions of $\mathrm{CO}_{2}$ for various biodiesel blend fuels.

Figure 12 presents UHC emissions for all fuels and it shows that biodiesel blends give lower figures than found for diesel fuel. POME B25 combustion shows a falling UHC emission to 0 at $\varphi$ of 0.8 to 1.1. The lower UHC emissions are related to the $\mathrm{O}_{2}$ content of the biodiesel fuel which can help biodiesel combustion. Exhaust temperature is an important parameter that influences the combustion temperature in the chamber, and this relates to $\mathrm{NO}_{\mathrm{x}}$ emissions. Normally, the exhaust temperature for biodiesel combustion will be high. As is shown in Figure 13, the exhaust temperatures of biodiesel blends are higher than that of diesel fuel. The exhaust temperature for JOME B25 blend and COME B25 blend combustion were respectively $5 \%$ and $4 \%$ more on average compared to that for diesel fuel combustion. In the lean state of combustion, POME B25 blend had a slightly higher temperature of about $5 \%$ more on average, and this dropped drastically after an equivalence ratio of 0.8 . This condition happened due to inappropriate mixing of the air and fuel, due to the large droplet size which could not adequately mix with air to enable a complete burn.

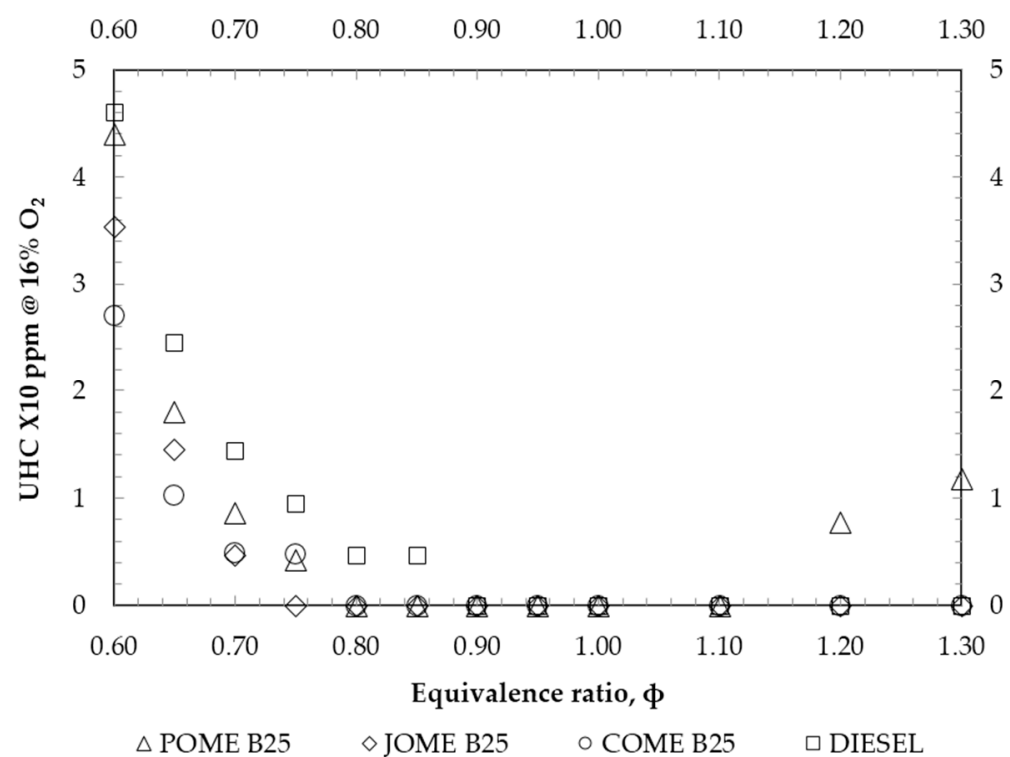

Figure 12. Emissions of UHC for various biodiesel blend fuels. 


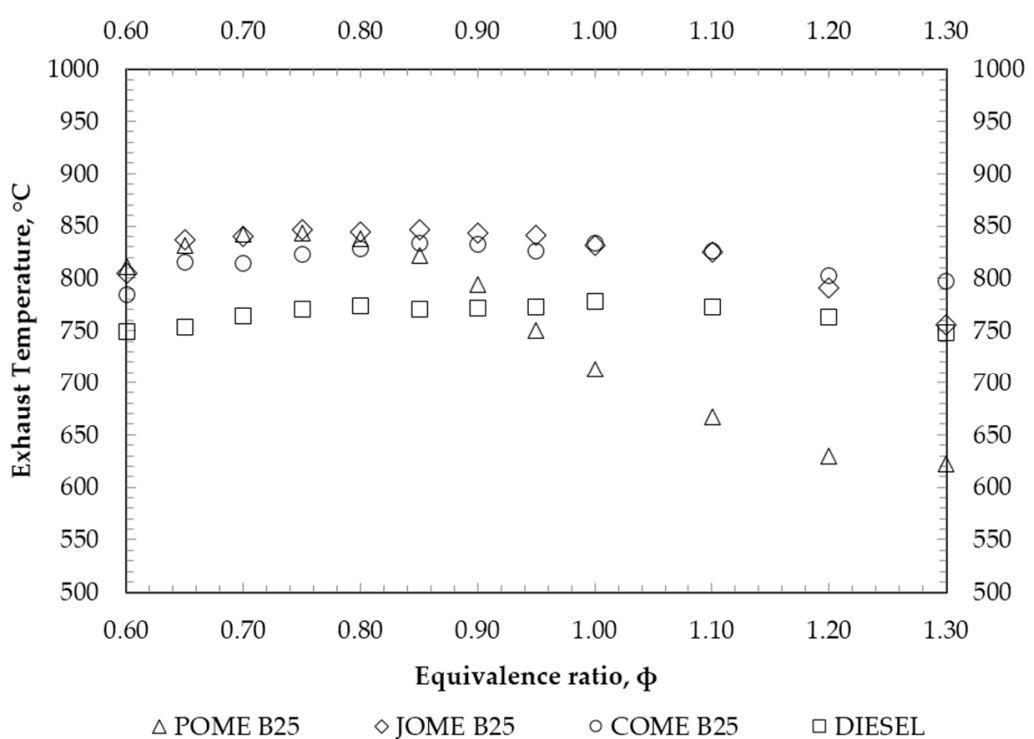

Figure 13. Exhaust temperature for various biodiesel blend fuels.

Figure 14a-d show comparisons of the differences between biodiesel blend emissions compared to diesel fuel emissions. The graphs present $\mathrm{NO}_{\mathrm{x}}, \mathrm{CO}, \mathrm{SO}_{2}$ and $\mathrm{UHC}$ emissions for various biodiesel blends including JOME B25, POME B25 and COME B25. As mentioned earlier, the oxygen contents of the biodiesel cause a higher combustion temperature and the emission of more $\mathrm{NO}_{\mathrm{x}}$. The biodiesel blend fuels contain more oxygen and this factor improves their combustion intensity.

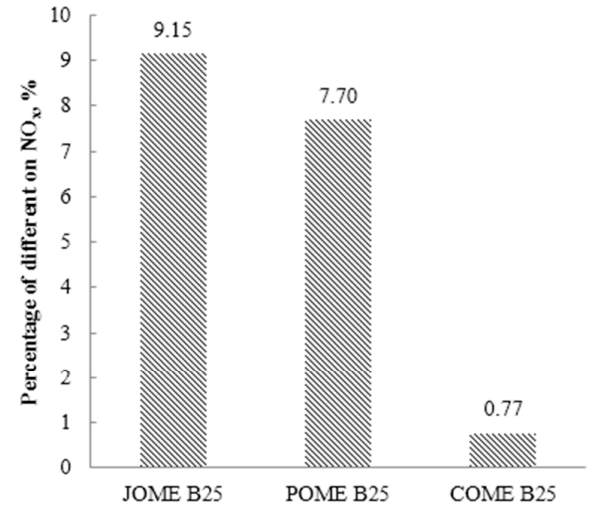

(a)

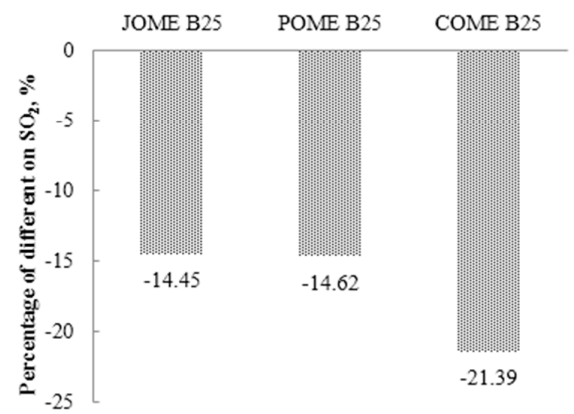

(c)

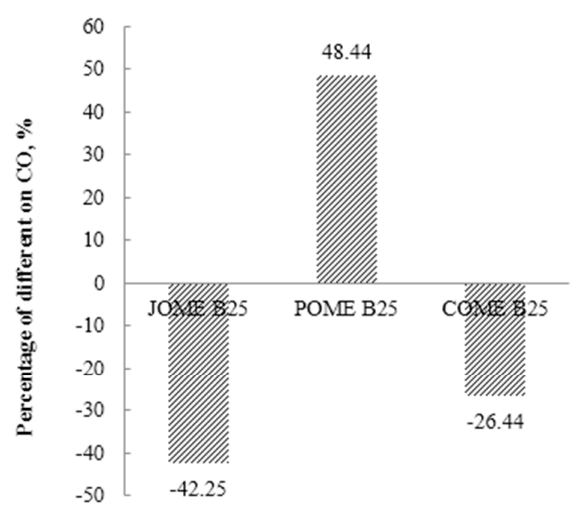

(b)

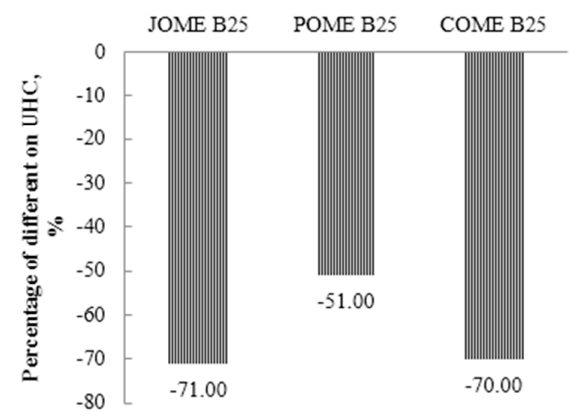

(d)

Figure 14. Percentages of biodiesel blend fuel emissions relative to diesel fuel. 
In Figure 14a, JOME B25 blend has the highest differences of $\mathrm{NO}_{\mathrm{x}}$ emissions on average compared to diesel fuel. Consequently, POME B25 and COME B25 blends displayed higher $\mathrm{NO}_{\mathrm{x}}$ emissions than diesel fuel, with increases of $7.7 \%$ and $0.77 \%$, respectively, due to their oxygen content. As expected, the $\mathrm{CO}$ emissions of biodiesel blends were reduced over the entire range of equivalence ratios except POME B25 which has an increased CO emission after reaching a stoichiometric state. On average, the CO emission of POME B25 was increased 48.44\% relative to diesel fuel as shown in Figure 14b. This might be caused by poor atomization during combustion, which results in inappropriate mixing with the supplied airflow, resulting in incomplete combustion. CO emissions of JOME B25 and COME B25 were reduced $42.25 \%$ and $26.44 \%$ respectively. Overall, these results indicate that complete combustion was achieved by biodiesel blends.

In Figure 14c, the average of $\mathrm{SO}_{2}$ emissions was improved by the decreasing of $\mathrm{SO}_{2}$ level in biodiesel blends. In fact, the biodiesel fuel contains no sulfur or in some cases very low sulfur after production by the acid-catalyzed esterification process. On average, JOME B25 has the lowest improvement of reduction in $\mathrm{CO}$ emission because it went through the acid-catalyzed esterification process before the transesterification process. During combustion, JOME B25 produced more $\mathrm{SO}_{2}$ that other biodiesel blends.

JOME B25 produced the lowest UHC emission levels compared to diesel fuel, specifically in the stoichiometric to rich region of combustion as shown in Figure 14d. On average, JOME B25 showed a 71\% reduction in UHC emissions relative to diesel fuel. This was followed by COME B25 and POME B25, where the UHC emissions were reduced $70 \%$ and $51 \%$, respectively.

\section{Conclusions}

The experimental results obtained from different $\mathrm{S}_{\mathrm{N}}$ values of diesel combustion and combustion of biodiesel blends with higher swirling flow showed significant reductions in $\mathrm{CO}, \mathrm{SO}_{2}$ and $\mathrm{UHC}$ emissions. Higher $\mathrm{S}_{\mathrm{N}}$ resulted in reduced emissions levels due to higher recirculation in the combustion zones. Further areas of study assessed the combustion qualities and parameters of different types of biodiesel produced from jatropha, palm and coconut oil feedstocks. The CO emissions of POME B25 blend were reduced within a certain range of air fuel ratios and continued to increase towards the stoichiometric and rich combustion regions. Overall, $\mathrm{NO}_{\mathrm{x}}$ emissions for all types of biodiesel were increased due to the high oxygen content in biodiesel fuel and higher cetane number. Thus, the combustion of biodiesel blends results in higher temperatures during combustion. Biodiesel fuel contains a higher oxygen content which leads to prolonged and more complete combustion and which results in lower $\mathrm{CO}, \mathrm{SO}_{2}$ and $\mathrm{UHC}$ emissions. On average, all the emissions produced in flue gases have similar trends as diesel fuel using a liquid fuel burner. Therefore, blending the biodiesel fuel helps to significantly improve emissions, which means that biodiesel fuels should be considered as good alternative fuels in liquid fuel burner applications.

Acknowledgments: The authors would like to thankful to Ministry of Higher Education (MOHE) and Universiti Teknologi Malaysia (UTM) for their funding under GUP Grant 4J149 (Mohammad Nazri Mohd. Jaafar, Project Leader).

Author Contributions: Norwazan Abdul Rahim performed the experiments, produced the samples, analyzed the data and wrote the paper; Mohammad Nazri Mohd. Jaafar and Hazri Farouk Elraheem conceived and prepared the materials include reviewed the manuscript; Syazwana Sapee contributed with preparation of materials, produced the samples and characterization of final samples.

Conflicts of Interest: The authors declare no conflicts of interest.

\section{References}

1. Ng, H.K.; Gan, S. Combustion performance and exhaust emissions from the non-pressurised combustion of palm oil biodiesel blends. Appl. Therm. Eng. 2010, 30, 2476-2484. [CrossRef]

2. Yang, P.M.; Lin, K.C.; Lin, Y.C.; Jhang, S.R.; Chen, S.C. Emission evaluation of a diesel engine generator operating with a proportion of isobutanol as a fuel additive in biodiesel blends. Appl. Therm. Eng. 2016, 100, 628-635. [CrossRef] 
3. Anand, K.; Sharma, R.P.; Mehta, P.S. A comprehensive approach for estimating thermo-physical properties of biodiesel fuels. Appl. Therm. Eng. 2011, 31, 235-242. [CrossRef]

4. Jindal, S.; Nandwana, B.P.; Rathore, N.S.; Vashistha, V. Experimental investigation of the effect of compression ratio and injection pressure in a direct injection diesel engine running on Jatropha methyl ester. Appl. Therm. Eng. 2010, 30, 442-448. [CrossRef]

5. Sharma, Y.C.; Singh, B. Development of biodiesel from karanja, a tree found in rural India. Fuel 2008, 87, 1740-1742. [CrossRef]

6. Atabani, A.E.; Silitonga, A.S.; Badruddin, I.A.; Mahlia, T.M.I.; Masjuki, H.H.; Mekhilef, S. A comprehensive review on biodiesel as an alternative energy resource and its characteristics. Renew. Sustain. Energy Rev. 2012, 16, 2070-2093. [CrossRef]

7. Abedin, M.J.; Masjuki, H.H.; Kalam, M.A.; Sanjid, A.; Ashraful, A.M. Combustion, performance, and emission characteristics of low heat rejection engine operating on various biodiesels and vegetable oils. Energy Convers. Manag. 2014, 85, 173-189. [CrossRef]

8. Darnoko, D.; Munir, C. Kinetics of Palm Oil Transesterification in a Batch Reactor. J. Am. Oil Chem. Soc. 2000, 77, 1263-1267. [CrossRef]

9. Moser, B.R. Influence of extended storage on fuel properties of methyl esters prepared from canola, palm, soybean and sunflowers. Renew. Energy 2011, 36, 1221-1226. [CrossRef]

10. Habibullah, M.; Masjuki, H.H.; Kalam, M.A.; Rizwanul Fattah, I.M.; Ashraful, A.M.; Mobarak, H.M. Biodiesel production and performance evaluation of coconut, palm and their combined blend with diesel in a single-cylinder diesel engine. Energy Convers. Manag. 2014, 87, 250-257. [CrossRef]

11. How, H.G.; Masjuki, H.H.; Kalam, M.A.; Teoh, Y.H. An investigation of the engine performance, emissions and combustion characteristics of coconut biodiesel in a high-pressure common-rail diesel engine. Energy 2014, 69, 749-759. [CrossRef]

12. Nakpong, P.; Wootthikanokkhan, S. High free fatty acid coconut oil as a potential feedstock for biodiesel production in Thailand. Renew. Energy 2010, 35, 1682-1687. [CrossRef]

13. Banapurmath, N.R.; Tewari, P.G.; Hosmath, R.S. Performance and emission characteristics of a DI compression ignition engine operated on Honge, Jatropha and sesame oil methyl ester. Renew. Energy 2008, 33, 1982-1988. [CrossRef]

14. Liu, Y.; Lu, H.; Jiang, W.; Li, D.; Liu, S.; Liang, B. Biodiesel Production from Crude Jatropha curcas L. Oil with Trace Acid Catalyst. Chin. J. Chem. Eng. 2012, 20, 740-746. [CrossRef]

15. Deng, X.; Fang, Z.; Liu, Y. Ultrasonic transesterification of Jatropha curcas L. oil to biodiesel by a two-step process. Energy Convers. Manag. 2010, 51, 2802-2807. [CrossRef]

16. Juan, J.C.; Kartika, D.A.; Wu, T.Y.; Hun, T.Y.Y. Biodiesel production from Jatropha oil by catalytic and non-catalytic approaches: An overview. Bioresour. Technol. 2011, 102, 452-460. [CrossRef] [PubMed]

17. El-Kasaby, M.; Nemit-allah, M.A. Experimental investigations of ignition delay period and performance of a diesel engine operated with Jatropha oil biodiesel. Alex. Eng. J. 2013, 52, 141-149. [CrossRef]

18. Sahoo, P.K.; Das, L.M. Combustion analysis of Jatropha, karanja and Polanga based biodiesel as fuel in a diesel engine. Fuel 2009, 88, 994-999. [CrossRef]

19. Lu, H.; Liu, Y.; Zhou, H.; Yang, Y.; Chen, M.; Liang, B. Production of biodiesel from Jatropha curcas L. oil. Comput. Chem. Eng. 2009, 33, 1091-1096. [CrossRef]

20. Yunus, S.; Rashid, A.A.; Abdullah, N.R.; Mamat, R.; Latip, S.A. Emissions of Transesterification Jatropha-Palm Blended Biodiesel. Procedia Eng. 2013, 68, 265-270. [CrossRef]

21. Rehman, A.; Phalke, D.R.; Pandey, R. Alternative fuel for gas turbine: Esterified jatropha oil-diesel blend. Renew. Energy 2011, 36, 2635-2640. [CrossRef]

22. Ling, Z.; Zeng, X.; Ren, T.; Xu, H. Establishing a low-NOx and high-burnout performance in a large-scale, deep-air staging laboratory furnace fired by a heavy-oil swirl burner. Appl. Therm. Eng. 2015, 79, 117-123. [CrossRef]

23. Sáez, A.; Flores-Maradiaga, A.; Toledo, M. Liquid butane as an alternative fuel for diesel oil burners. Appl. Therm. Eng. 2012, 45-46, 1-8. [CrossRef]

24. Feyz, M.E.; Esfahani, J.A.; Pishbin, I.; Modarres Razavi, S.M.R. Effect of recess length on the flame parameters and combustion performance of a low swirl burner. Appl. Therm. Eng. 2015, 89, 609-617. [CrossRef] 
25. Ghorbani, A.; Bazooyar, B.; Shariati, A.; Jokar, S.M.; Ajami, H. A comparative study of combustion performance and emission of biodiesel blends and diesel in an experimental boiler. Appl. Energy 2011, 88, 4725-4732. [CrossRef]

26. Buyukkaya, E. Effects of biodiesel on a DI diesel engine performance, emission and combustion characteristics. Fuel 2010, 89, 3099-3105. [CrossRef]

27. Lin, B.F.; Huang, J.H.; Huang, D.Y. Experimental study of the effects of vegetable oil methyl ester on DI diesel engine performance characteristics and pollutant emissions. Fuel 2009, 88, 1779-1785. [CrossRef]

28. Hashimoto, N.; Ozawa, Y.; Mori, N.; Yuri, I.; Hisamatsu, T. Fundamental combustion characteristics of palm methyl ester (PME) as alternative fuel for gas turbine. Fuel 2008, 87, 3373-3378. [CrossRef]

29. Sharon, H.; Karuppasamy, K.; Soban Kumar, D.R.; Sundaresan, A. A test on DI diesel engine fueled with methyl esters of used palm oil. Renew. Energy 2012, 47, 160-166. [CrossRef]

30. Özcanli, M.; Serin, H.; Saribiyik, O.Y.; Aydin, K.; Serin, S. Performance and Emission Studies of Castor Bean (ricinus Communis) Oil Biodiesel and Its Blends with Diesel Fuel. Energy Sources A 2012, 34, 1808-1814. [CrossRef]

31. Atadashi, I.M.; Aroua, M.K.; Abdul Aziz, A. High quality biodiesel and its diesel engine application: A review. Renew. Sustain. Energy Rev. 2012, 14, 1999-2008. [CrossRef]

32. Rakopoulos, C.D.; Antonopoulos, K.A.; Rakopoulos, D.C.; Hountalas, D.T.; Giakoumis, E.G. Comparative performances and emissions study of a direct injection Diesel engine blends of Diesel fuel with vegetables or bio-diesels of various origins. Energy Convers. Manag. 2006, 47, 3271-3287. [CrossRef]

33. Iqbal, M.A.; Varman, M.; Masjuki, H.H.; Kalam, M.A.; Hossain, S.; Sayeed, I. Tailoring fuel properties using jatropha, palm and coconut biodiesel to improve CI engine performance and emissions characteristics. J. Clean. 2015, 101, 262-270. [CrossRef]

34. Palash, S.M.; Kalam, M.A.; Masjuki, H.H.; Masum, B.M.; Rizwanul Fattah, I.M.; Mofijur, M. Impacts of biodiesel combustion on NOx emissions and their reduction approaches. Renew. Sustain. Energy Rev. 2013, 23, 473-490. [CrossRef]

35. Sahoo, P.K.; Das, L.M.; Babu, M.K.G.; Naik, S.N. Biodiesel development from high acid value polanga seed oil and performance evaluation in a CI engine. Fuel 2007, 86, 448-454. [CrossRef]

36. Atabani, A.E.; Silitonga, A.S.; Ong, H.C.; Mahlia, T.M.I.; Masjuki, H.H.; Badruddin, I.A.; Fayaz, H. Non-edible vegetable oils: A critical evaluation of oil extraction, fatty acid compositions, biodiesel production, characteristics, engine performance and emissions production. Renew. Sustain. Energy Rev. 2013, 18, $211-245$. [CrossRef]

37. Mofijur, M.; Masjuki, H.H.; Kalam, M.A.; Atabani, A.E.; Rizwanul Fatah, I.M.; Mobarak, H.M. Comparative evaluation of performance and emission characteristics of Moringa oleifera, and Palm oil based biodiesel in a diesel engine. Ind. Crop. Prod. 2014, 53, 78-84. [CrossRef]

38. Bojan, S.G.; Durairaj, S.K. Producing Biodiesel from High Free Fatty Acid Jatropha curcas Oil by A Two Step Method-An Indian Case Study. J. Sustain. Energy Environ. 2012, 3, 63-66.

39. Leung, D.Y.C.; Wu, X.; Leung, M.K.H. A review on biodiesel production using catalyzed transesterification. Appl. Energy 2010, 87, 1083-1095. [CrossRef]

40. Baroutian, S.; Aroua, M.K.; Abdul Raman, A.A.; Nik Sulaiman, N.M. Potassium hydroxide catalyst supported on palm shell activated carbon for transesterification of palm oil. Fuel Process. Technol. 2010, 91, 1378-1385. [CrossRef]

41. Lam, M.K.; Lee, K.T.; Mohamed, A.R. Homogeneous, heterogeneous and enzymatic catalysis for transesterification of high free fatty acid oil (waste cooking oil) to biodiesel: A review. Biotechnol. Adv. 2010, 28, 500-518. [CrossRef] [PubMed]

42. Borges, M.E.; Díaz, L. Recent developments on heterogeneous catalysts for biodiesel production by oil esterification and transesterification reactions: A review. Renew. Sustain. Energy Rev. 2012, 16, 2839-2849. [CrossRef]

43. May, C.Y.; Liang, Y.C.; Foon, C.S.; Ngan, M.A.; Hook, C.C.; Basiron, Y. Key fuel properties of palm oil alkyl esters. Fuel 2005, 84, 1717-1720. [CrossRef]

44. Zhang, J.; Chen, S.; Yang, R.; Yan, Y. Biodiesel production from vegetable oil using heterogeneous acid and alkali catalyst. Fuel 2010, 89, 2939-2944. [CrossRef]

45. Hashimoto, N.; Nishida, H.; Ozawa, Y. Fundamental combustion characteristics of Jatropha oil as alternative fuel for gas turbines. Fuel 2014, 126, 194-201. [CrossRef] 
46. Beer, J.M.; Chigier, N.A. Combustion Aerodynamics; Applied Science Publishers: London, UK, 1974.

47. Lilley, D.G. Prediction of Inert Turbulent Swirl Flows. AIAA J. 1973, 11, 955-960. [CrossRef]

48. Lefebvre, A.H. The role of fuel preparation in low emissions combustion. J. Eng. Gas Turbines Power 1995, 117, 617-654. [CrossRef]

49. Gumus, M.; Sayin, C.; Canakci, M. The impact of fuel injection pressure on the exhaust emissions of a direct injection diesel engine fueled with biodiesel-diesel fuel blends. Fuel 2012, 95, 486-494. [CrossRef]

50. Kalam, M.A.; Masjuki, H.H.; Jayed, M.H.; Liaquat, A.M. Emission and performance characteristics of an indirect ignition diesel engine fuelled with waste cooking oil. Energy 2011, 36, 397-402. [CrossRef]

(C) 2016 by the authors; licensee MDPI, Basel, Switzerland. This article is an open access article distributed under the terms and conditions of the Creative Commons Attribution (CC-BY) license (http://creativecommons.org/licenses/by/4.0/). 